\title{
Adipocytes in Skin Health and Disease
}

\author{
Guillermo Rivera-Gonzalez ${ }^{1}$, Brett Shook ${ }^{1}$, and Valerie Horsley \\ Department of Molecular, Cellular and Developmental Biology, Yale University, New Haven, \\ Connecticut 06520 \\ Correspondence: valerie.horsley@yale.edu
}

Adipocytes are intimately associated with the dermal compartment of the skin, existing in a specialized dermal depot and displaying dynamic changes in size during tissue homeostasis. However, the roles of adipocytes in cutaneous biology and disease are not well understood. Traditionally, adipocytes within tissues were thought to act as reservoirs of energy, as thermal, or as structural support. In this review, we discuss recent studies revealing the cellular basis of the dynamic development and regenerative capacity of dermal adipocytes associated with the hair cycle and following injury. We discuss and speculate on potential roles of dermal adipocytes in cutaneous biology with an emphasis on communication during hair follicle growth and wound healing. Finally, we explore how alterations in the dermal adipose tissue may support clinical manifestations of cutaneous diseases such as lipodystrophy, obesity, and alopecia.

\section{ADIPOCYTE DEVELOPMENT AND HOMEOSTASIS IN THE SKIN}

In mammals, white adipose tissue (WAT) forms at specific bodily sites or depots. Major sites of adipocyte development include the visceral depot in the abdomen, subcutaneous adipocytes below the skin, and dermal adipocytes within the dermis of the skin (Gesta et al. 2007). The timing of adipocyte formation and gene expression patterns is different between distinct adipose depots (Gesta 2006). Mature dermal adipocytes form postnatally after the formation of the hair follicle (Hausman et al. 1981). However, adipocyte precursor cells are present in murine embryonic skin by E14 (Wojciechowicz et al. 2013) and cells expressing $\mathrm{C} / \mathrm{EBP} \alpha$, which can control adipocyte differentiation, exist within the dermis of mouse skin a few days before birth (Wojciechowicz et al. 2008), suggesting that adipocyte precursor cells exist in the skin during the formation of the dermis.

The developmental origin of adipocytes has not fully been defined. Genetic lineage tracing using mice expressing Cre recombinase under the control of the Sox10 promoter, expressed in neural crest cells, revealed that many mesenchymal cell types including cephalic adipocytes in the salivary gland and ear are of neural crest origin, but not adipocytes in trunk depots, such as subcutaneous adipocytes (Le Douarin 2004). Recent studies have shown that Pdgfr- $\alpha$ expressing cells form adipocytes during development in several depots (Fig. 1) (Berry and

\footnotetext{
${ }^{1}$ These authors contributed equally to this work.

Editors: Anthony E. Oro and Fiona M. Watt

Additional Perspectives on The Skin and Its Diseases available at www.perspectivesinmedicine.org

Copyright (C) 2014 Cold Spring Harbor Laboratory Press; all rights reserved; doi: 10.1101/cshperspect.a015271

Cite this article as Cold Spring Harb Perspect Med 2014;4:a015271
} 
G. Rivera-Gonzalez et al.

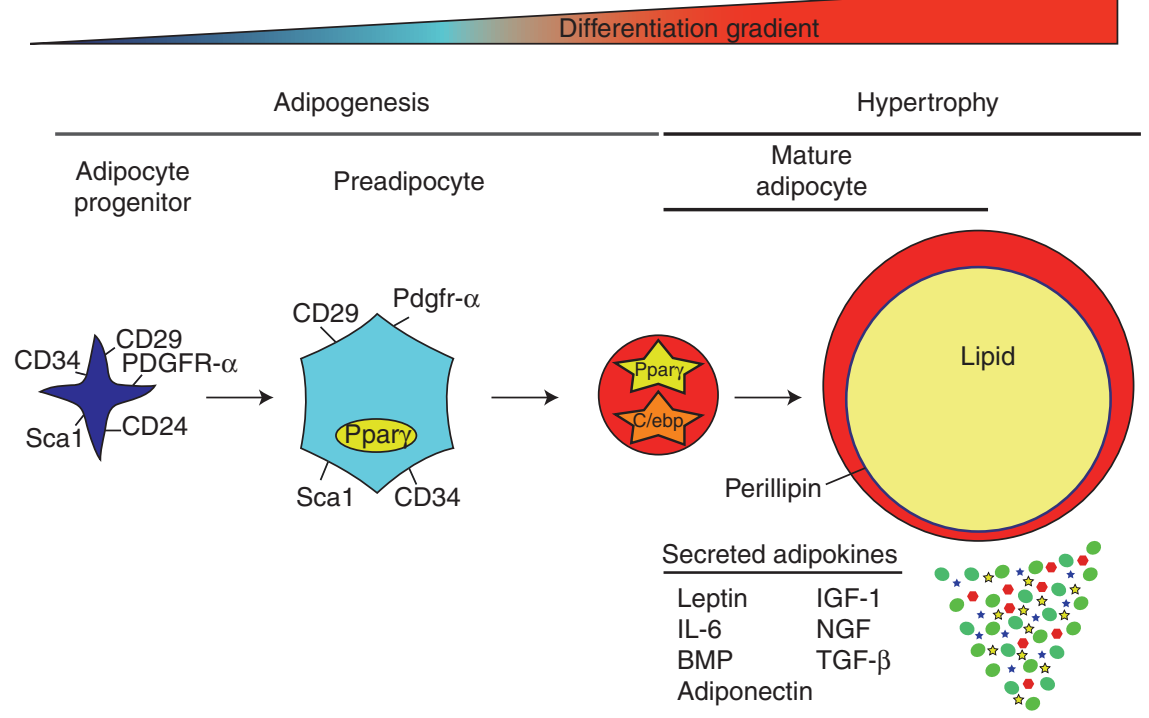

Figure 1. Mechanisms of adipose tissue growth. Adipose tissue growth can occur through two different mechanisms: adipogenesis and hypertrophy. Adipogenesis generates new mature adipocytes through proliferation and differentiation of proliferative adipocyte precursor cells (identified by the cell surface markers Lin-, CD34, CD29, Sca1, CD24, and PDGFR- $\alpha$ ). These cells give rise to preadipocytes that lose CD24 expression and begin to express higher levels of adipogenic transcription factors such as PPAR $\gamma$. Preadipocytes differentiate into postmitotic mature adipocytes and can grow in size as they fill with lipid during hypertrophy. Mature adipocytes express perilipin and secrete adipokines that have the potential to impact skin biology.

Rodeheffer 2013). However, because Pdgfr- $\alpha$ is expressed by multiple mesenchymal lineages (Karlsson et al. 1999; Collins et al. 2011), the precise developmental origin of dermal adipocytes is unknown.

Classic studies in the 1950s studying the death and regrowth of the postnatal hair follicle noted that the dermal adipocyte layer dramatically changes its thickness in synchrony with the spontaneous regeneration of the hair follicle (Fig. 2) (Chase et al. 1953). The hair follicle is maintained by cyclic growth (anagen), death (catagen), and quiescent (telogen) stages during its maintenance. The initiation of hair regrowth involves the activation of epithelial stem cells in the bulge region of the hair follicle (Cotsarelis et al. 1990; Blanpain et al. 2004; Zhang et al. 2009) and their interaction with mesenchymal cells in the dermal papillae (Jahoda et al. 1984; Rompolas et al. 2012). During hair follicle morphogenesis, lipid-filled dermal adipocytes surround the growing hair follicle (Fig. 2). On follicular regression, the adipocyte layer diminishes to a thin layer of mature adipocytes underneath the dermal papillae. Following initiation of hair follicle growth, the size of the dermal adipocyte layer expands.

The dynamic nature of dermal adipocytes during the hair cycle is controlled in part by the formation of new mature adipocytes by immature adipocyte precursor cells (Fig. 1). Immature adipocyte lineage cells can be identified based on their expression of CD34, CD29, and Scal (Rodeheffer et al. 2008; Festa et al. 2011; Berry and Rodeheffer 2013). Labeling of proliferative cells during the initiation of hair growth revealed that immature adipocyte precursor cells are activated to proliferate in parallel with the hair cycle and new mature adipocytes are formed by proliferative cells (Festa et al. 2011). Furthermore, treatment of mice during the initiation of hair growth with a pharmacological inhibitor of a key adipogenic transcription factor, PPAR $\gamma$, blocks the growth of dermal adipo- 


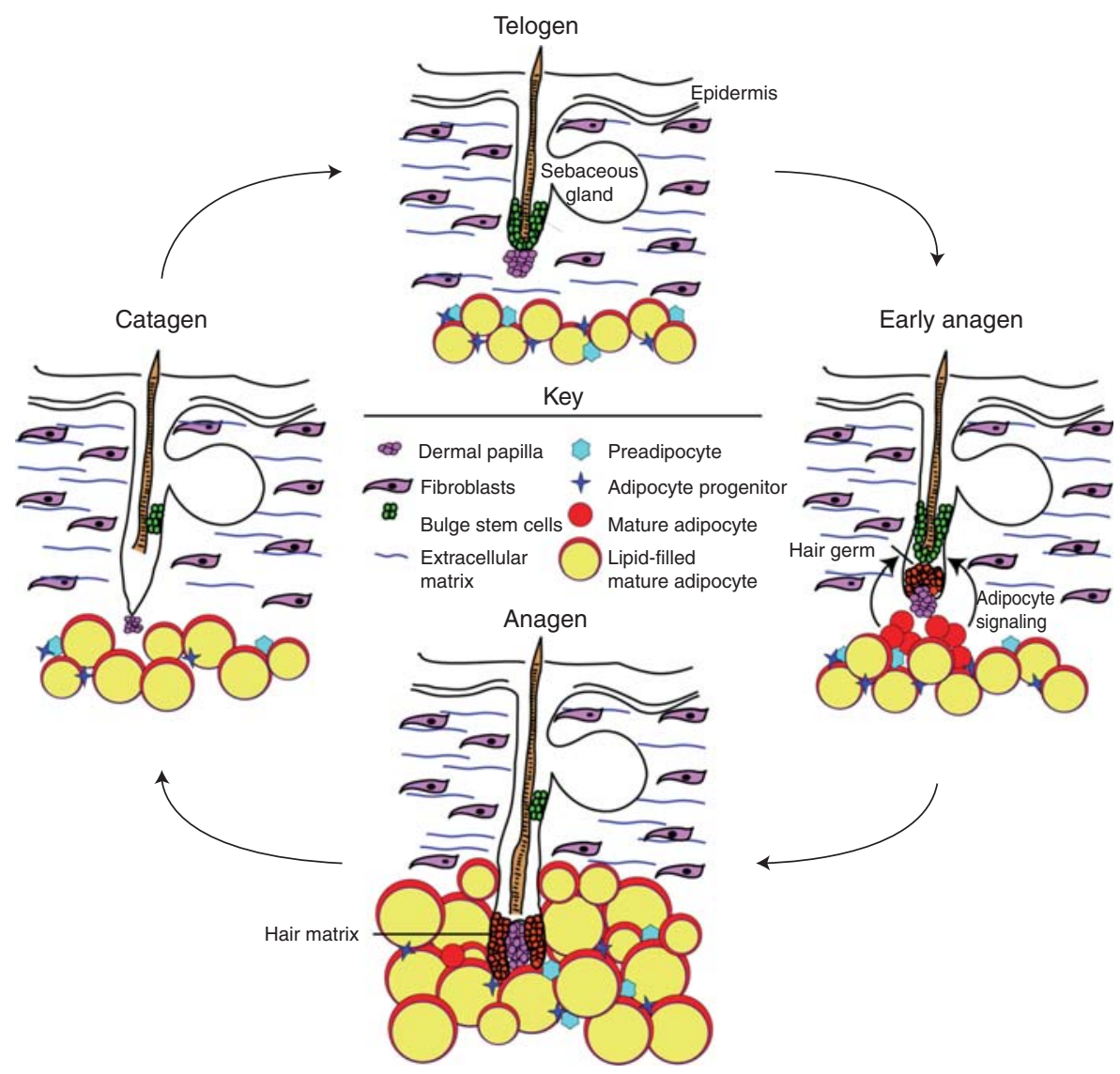

Figure 2. Changes in dermal adipose tissue during the hair follicle cycle. During the transition of the hair follicle from rest (telogen) to growth (anagen), dermal adipose tissue increases in size via activation of immature adipocyte precursor cells. These cells generate an increased number of adipocytes that, via hypertrophy, grow in size to surround the hair follicle during anagen. As the hair follicle regresses (catagen), dermal adipose tissue significantly decreases in size via unknown mechanisms.

cytes during the hair cycle. Thus, adipogenesis within the dermal adipocyte depot occurs in parallel with the hair follicle cycle.

Adipogenesis of dermal adipocytes also occurs following injury (Schmidt and Horsley 2013) as the ensuing wound-healing process repairs epidermal and dermal integrity and composition to its original structure (Fig. 3) (Alexaki et al. 2012; Forcheron et al. 2012; Riccobono et al. 2012; Schmidt and Horsley 2013). Immediately following a skin injury, the inflammatory response protects the damaged skin from external pathogens and clears cellular debris created by the injury (Delavary et al. 2011). Immune cells initiate the proliferative response by which ker- atinocytes and fibroblasts proliferate and migrate to restore the epidermal barrier and initiate dermal repair, respectively. Adiponectin- and perilipin-expressing adipocytes repopulate skin wounds during the proliferative stage of healing concomitant with fibroblast activation and migration (Schmidt and Horsley 2013). This repopulation of adipocytes following wounding is associated with proliferation of adipocyte precursor cells and can be inhibited by pharmacological inhibition of PPAR $\gamma$, indicating that adipogenesis occurs during wound healing.

In general, the cellular and molecular pathways that promote adipogenesis in vivo are not well understood. The dynamic nature of dermal 
G. Rivera-Gonzalez et al.
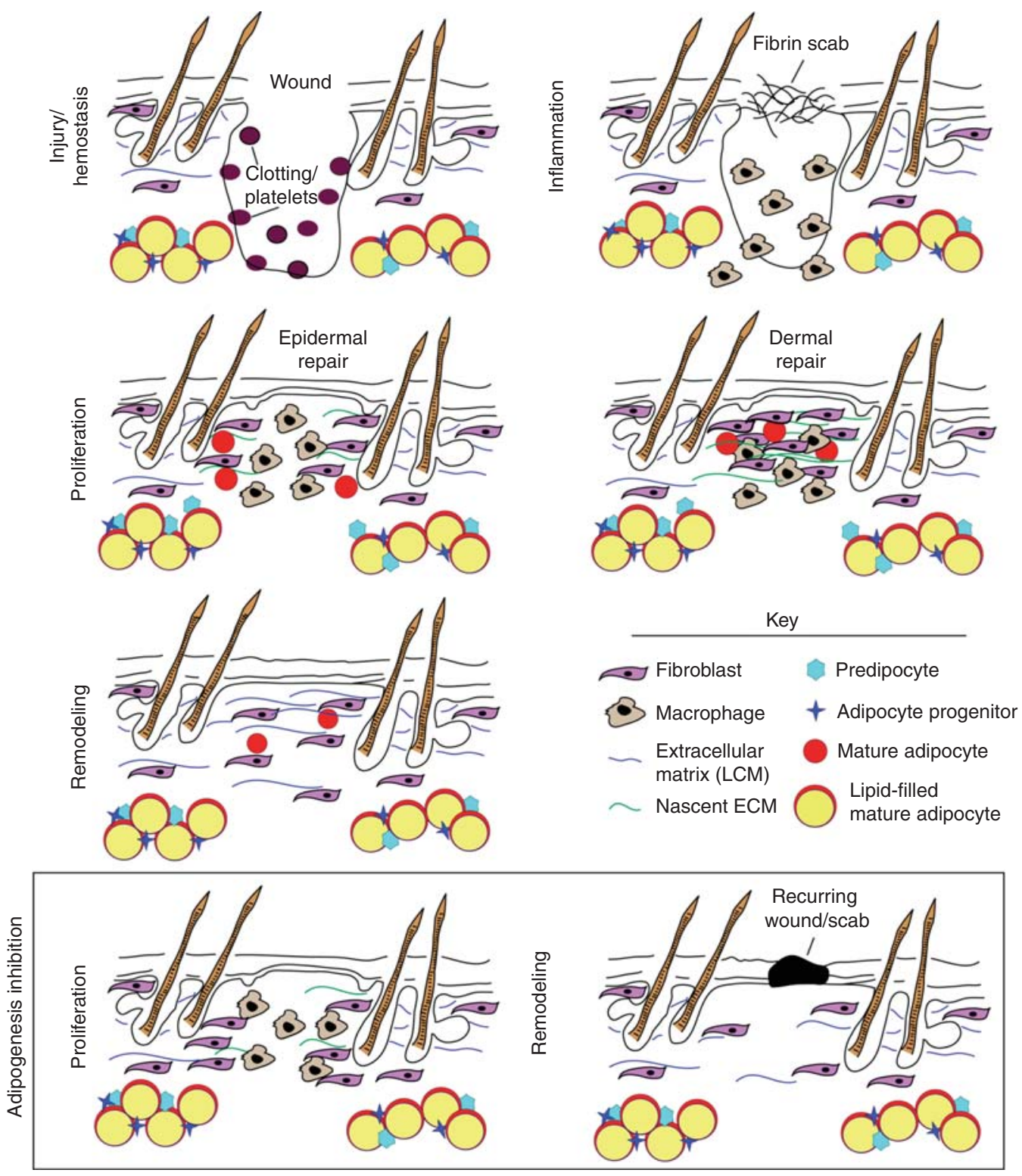

Figure 3. The role of adipocytes in wound healing. Wound healing occurs in four main stages: injury, inflammation, proliferation, and remodeling. Immediately after wounding, platelets generate a clot that prevents blood loss and generates a scab. Over the next few days, immune cells infiltrate the wounded area to clear debris. During the proliferation phase, growth factors and signaling molecules promote proliferation and migration of keratinocytes to reseal the epithelial barrier. Concurrent but independent of the keratinocyte-mediated proliferative phase, adipocyte precursor cells are activated to generate mature adipocytes, which along with fibroblasts repopulate the wound bed, leading to production of extracellular matrix and wound closure. The ensuing remodeling of wound bed extracellular matrix (ECM) can last several weeks. When the production of newly generated mature adipocytes is prevented, fibroblast migration into the wound bed is severely reduced, leading to diminished ECM production. Whereas re-epithelialization is normal in the early wound healing process in the absence of adipocytes, dermal defects cause deficiencies in the long-term wound integrity leading to wound recurrence. 
adipocytes during the hair cycle and wound healing is distinct from the slow turnover of adipocytes within other depots (Spalding et al. 2008), suggesting that distinct mechanisms within the skin control dermal adipogenesis. Although adipocyte precursor cells within visceral and subcutaneous adipose tissue can be activated following stimulation of $\beta$-adrenergic signaling and high fat diet feeding of mice (Joe et al. 2009; Lee et al. 2012), the mechanisms by which these stimuli activate adipogenesis have not been identified. Several in vitro studies using adipogenic fibroblast cell lines have implicated several signaling pathways in regulation of adipocyte fate. BMP signaling promotes adipogenic differentiation of the fibroblast cell line, C3H10T1/2 (Huang et al. 2009). In contrast, Wnt signaling prevents adipogenic differentiation of fibroblast cell lines (Ross et al. 2000) via repression of two key transcription factors involved in adipogenic differentiation, PPAR $\gamma$ and $\mathrm{C} / \mathrm{EBP} \alpha$ (Christodoulides et al. 2009). Adipogenic potential of these cell lines is blocked by Hedgehog signaling, which increases differentiation of fibroblast cells to nonadipogenic cell types such as bone (Spinella-Jaegle et al. 2001). Whether these nutritional and signaling pathways influence the activation and maturation of immature adipogenic cells within adipocyte depots including the dermal depot of the skin has yet to be determined.

The differentiation of adipocytes into mature lipid-filled cells occurs through a transcriptional network that involves multiple transcription factors and leads to lipid filling (Rosen and Spiegelman 2006). Inactivation of AP1 and KLF, transcription factors expressed at early stages of the differentiation process, results in poor adipocyte differentiation of adipogenic cell lines (Herrmann et al. 2003; Oishi et al. 2005). The most crucial set of events in preadipocyte differentiation is the activation of CREB followed by the induction of C/EBP and PPAR $\gamma$ (Tontonoz et al. 1994; Yeh et al. 1995; Zhang et al. 2004). Preadipocytes enter the cell cycle and C/EBP becomes active to stop clonal expansion, followed by PPAR $\gamma$ expression to initiate the expression of several lipogenic genes (Morrison and Farmer 1999; Tang et al. 2003). Transgenic AZIP mice expressing a dominant negative form of C/EBP under the control of the FABP4 promoter abrogates the formation of mature white adipocytes in all adipocyte depots including the skin, supporting the importance of C/EBP in adipocyte formation in vivo (Moitra et al. 1998). PPAR $\gamma$ is also essential for mature adipocyte formation in the skin as indicated by the ability of pharmacological antagonists of PPAR $y$ to block adipogenesis associated with the hair cycle and wound healing. The inhibition of adipogenesis in these mice has revealed novel aspects regarding the function of adipocytes in the skin as discussed below.

\section{THE FUNCTION OF DERMAL ADIPOCYTES DURING HAIR REGENERATION}

Several mouse models with defects in dermal adipose tissue have revealed regulatory roles for dermal adipocytes during the hair cycle. Mice expressing transgenes or lacking genes involved in fatty acid (FA) biology display defects in both dermal adipose tissue and hair growth (Jong et al. 1998; Chen et al. 2002; Herrmann et al. 2003; Stone et al. 2004; Weger and Schlake 2005). Furthermore, mice lacking EGFR show a delayed entry into anagen as well as a reduced number of dermal adipocytes (Maklad et al. 2009). Although dermal and epidermal defects occur in these mouse models, because these mutations affect multiple cell types in the skin, the precise role of adipocytes in the skin was not revealed from these studies.

Mice with defects in adipogenesis, either through the short-term pharmacological inhibition of PPAR $\gamma$ during adipogenesis or by genetic deletion of the transcription factor $E b f 1$ revealed a role for immature adipocytes in the promotion of hair cycling. Although Ebf1 is expressed within the dermal papillae during hair growth, transplantation of WT follicles onto adipocytes of Ebf1 null mice blocked hair follicle growth, suggesting that hair growth defects in Ebf1 null mice are attributable to adipocyte dysfunction. Adipocyte lineage cells are also sufficient to drive precocious entry into anagen in resting follicles (Festa et al. 2011). Taken together with the ability of hair follicles to cycle in AZIP mice, which lack mature adipocytes, these data 
indicate that adipocyte precursor cells promote the initiation of hair growth.

Several signaling molecules have been implicated in the control of hair cycling including bone morphogenic proteins (BMPs) (Plikus et al. 2008; Rendl et al. 2008), fibroblast growth factor (FGF) (Rendl et al. 2005; Weger and Schlake 2005; Greco et al. 2009), platelet-derived growth factors (PDGFs) (Karlsson et al. 1999), and Wnt molecules (Millar 2006; Kobielak et al. 2007; Enshell-Seijffers et al. 2010). Dermal adipocytes have been shown to express both BMP and PDGF molecules (Plikus et al. 2008; Festa et al. 2011). Mice with defects in adipogenesis display decreased PDGF signaling and hair growth initiation can be rescued in Ebf1 null mice by dermal implantation of PDGF- $\alpha$ coated beads (Festa et al. 2011). This potential role of adipocyte-derived PDGF- $\alpha$ is corroborated by delayed hair follicle growth in $P d g f-\alpha-\mathrm{KO}$ mice (Karlsson et al. 1999). Mature adipocytes also express BMP molecules, which are essential for anagen induction (Plikus et al. 2008). Analysis of hair growth in mice harboring adipocytespecific deletion of key signaling factors will further reveal the role of adipocyte precursor cells during hair cycling.

\section{ADIPOCYTES DURING SKIN WOUND HEALING}

Several studies have revealed that the coordinated interplay between immune, epithelial, and fibroblast cells is essential for acute wound healing in the skin (Jackson et al. 2012). Analysis of mice with defects in adipogenesis revealed that adipocyte precursor cells also participate in the coordination of skin repair following injury (Fig. 3). AZIP mice, which lack mature white adipocytes, display defects in fibroblast recruitment into wound beds. Pharmacological inhibition of adipogenesis during wound healing also prevents fibroblast recruitment during wound healing. In vitro, fibroblast migration is significantly enhanced in the presence of adipocyte-conditioned media, suggesting that factors secreted by newly generated adipocytes are critical for proper fibroblast recruitment into the wound bed (Schmidt and Horsley 2013).
Whereas no detectable differences in re-epithelialization, revascularization, or immune cell biology occurs in wounded skin of mice with defects in adipogenesis, fibroblast defects in these mice ultimately result in decreased ECM deposition and wound instability (Schmidt and Horsley 2013). Thus, adipocytes promote fibroblast function during wound healing in the skin.

Interestingly, transplantation of mesenchymally derived cells that have adipogenic potential can enhance skin wound healing (Konno et al. 2013). Cells residing in the stromal fraction of adipose tissue have been shown to contribute to improved skin wound healing repair. Injection of mesenchymally derived cells that are Lin $^{-}$and express Sca-1, CD29, CD44, CD105 into healing wounds have been shown to enhance cutaneous wound healing and reduce scar formation (Jackson et al. 2012), yet the mechanisms and the fate of engrafted cells are poorly understood. Adipose-derived stromal cells have been reported to increase the rate of re-epithelialization and blood vessel density in skin wounds (Alexaki et al. 2012; Forcheron et al. 2012; Huang et al. 2012; Riccobono et al. 2012). Additionally, transplantation of adiposederived stromal cells into wound beds has been reported to change the phenotype of wound bed macrophages from pro- to anti-inflammatory (Ziboh et al. 1986; Jiang et al. 2013). Because mesenchymal cells can produce both fibroblast and adipocyte fates in vitro (Uezumi et al. 2011), it will be interesting to determine whether transplanted mesenchymal cells generate adipocyte lineage cells to enhance the wound healing process.

\section{ADIPOCYTES DURING SKIN AGING}

With age, skin undergoes a continual degeneration of multiple structural and functional characteristics, which may be linked to changes in dermal adipocytes. Whereas increases in visceral fat occur with age, other adipose tissue depots shrink during aging (Kuk et al. 2009; Tchkonia et al. 2010), including dermal adipose tissue (Luo et al. 2002; Tyner et al. 2002; Sun et al. 2004; Kondratov et al. 2006; Kuk et al. 2009; Tchkonia et al. 2010; Treiber et al. 2011; Bilkei- 
Gorzo et al. 2012). The papillary dermis also continually declines in thickness, which is characterized by decreased cellularity and a reduction in collagen deposition (Ashcroft et al. 1997; Varani et al. 2001). Given the possibility of a common fibro/adipogenic progenitor (FAP) in the skin, the shrinking of both the fibroblast-rich papillary dermis and the dermal adipose tissue may be linked. Alternatively, age may alter these dermal regions independently by altering the homeostasis of independent progenitor populations.

Another major change with age in the skin is the number of immune cells within the dermis with some cell populations elevated whereas others decreased (Thiers et al. 1984; Giangreco et al. 2008; Khavkin and Ellis 2011; Zouboulis and Makrantonaki 2011). These changes have been shown to alter the potential of follicular stem cells by directly signaling via Stat 3 (Doles et al. 2012). Given the ability of immune cells to influence adipocyte biology during obesity (Kanneganti and Dixit 2012; Schipper et al. 2012; Winer and Winer 2012), these changes in inflammation during age may also contribute to a reduction in dermal adipocytes.

An age-related attenuation of interfollicular epidermal function may also be linked to changes in dermal adipocytes. Epidermal barrier function declines with age resulting in increased permeability and water loss. A reduction in lipids in the stratum corneum and abnormal cholesterol synthesis has been implicated in these changes (Grove and Kligman 1983; Rogers et al. 1996). If dermal adipocytes are a local source of lipids within the skin, age-related changes in adipocyte biology may reduce an important lipid pool within the skin, contributing to stratum corneum defects.

The function and growth of epidermal appendages such as the hair follicle also dwindle with age. Hair loss is associated with accelerated aging phenotypes in mouse models and normal aging in humans (Harrison and Archer 1988; Courtois et al. 1995; Tyner et al. 2002; Trüeb 2005; Kondratov et al. 2006; Geyfman and Andersen 2010). Given the ability of immature adipocyte lineage cells to activate hair growth (Festa et al. 2011), a decline in adipogenesis in the skin may contribute to hair phenotypes associated with aging. Whereas the dynamic behavior of adipocyte lineage cells in aged skin has not been examined, immature adipocyte replication and adipogenesis declines with age in other depots (Djian et al. 1983; Kirkland et al. 1990; Schipper et al. 2008; Cartwright et al. 2010). The reduction in dermal adipose tissue with age suggests that adipocyte precursor cells may be lost or lose activity with age. Future work examining the self-renewal and activation potential of adipocyte precursor cells with age and a possible link with hair follicle maintenance will be an interesting area of future investigation.

In addition to these changes to skin homeostasis, wound healing in aged skin is slow and inefficient (Ashcroft et al. 1997, 2003; Gosain and DiPietro 2004). Proliferation of keratinocytes, fibroblasts, and endothelial cells is reduced in aged skin after wounding, resulting in defective re-epithelialization, collagen synthesis, and revascularization with age (Puolakkainen et al. 1995; Swift et al. 1999; Reed et al. 2001; Gosain and DiPietro 2004). Given the significance of adipocytes during wound healing (Schmidt and Horsley 2013), future studies examining the activation and molecular signals generated from adipocytes during wound healing could have tremendous translational value.

\section{POTENTIAL LINKS BETWEEN HORMONES AND ADIPOCYTES IN THE SKIN}

The homeostasis and function of white adipose tissue and skin biology can be altered by a wide variety of hormonal changes suggesting a potential role for hormones and dermal adipocytes in skin homeostasis. In particular, hypothalamic production of thyroid (TH) and growth hormone $(\mathrm{GH})$ has key roles in the regulation of WAT function (Carmean et al. 2013). Defective $\mathrm{TH}$ signaling increases adipocyte differentiation of preadipocyte 3T3L1 cells (Mishra et al. 2010) and in vivo WAT formation in mice (Ying et al. 2007). On the other hand, GH has been implicated in the regulation of lipolysis through activation of Stat5 within mature adipocytes (Fain et al. 1999; Moller et al. 2009). 
Both of these hormones can also alter skin biology. Although the effect of TH on dermal thickness remains controversial (Safer 2011), $\mathrm{TH}$ treatment can increase dermal fibroblast proliferation and diminish collagen and fibronectin production (de Rycker et al. 1984; $\mathrm{Mu}-$ rata et al. 1987). Administration of $\mathrm{TH}$ to mice also shortens telogen and anagen phases (Hale and Ebling 1979). Topical TH administration results in increased hair counts (Safer et al. 2001), whereas intraperitoneal TH shows the opposite result (Safer et al. 2003). Transgenic expression of GH can also change skin physiology by promoting skin growth and fibrosis. Interestingly these effects are only observed in males, suggesting a possible interaction with androgens (Wanke et al. 1999). Examining the potential role of these hormones in dermal adipocytes may reveal aspects of these physiological changes that are controlled by adipocytes.

Additional systemic hormones may play a role in governing skin homeostasis by altering dermal adipose tissue. Deletion of estrogen receptor $\alpha(E R \alpha)$ in mice leads to obesity (Heine et al. 2000), caused by adipocyte hyperplasia (Heine et al. 2000) and hypertrophy (Cooke et al. 2001; Penza et al. 2006). Estrogen has pleiotrophic roles on hair regeneration; it has been proposed to postpone the anagen-telogen transition, thereby increasing hair growth (Deplewski and Rosenfield 2000), but also to promote early entry into catagen and delay the transition from telogen into anagen (Chanda et al. 2000; Hu et al. 2012). Whether adipocytes in the skin are a source of estrogen that controls hair regeneration will be an interesting area of future investigation.

Androgens also play a pivotal role in adipose and skin biology. Mice that express enhanced levels of the androgen receptor (AR) show decreased fat mass and adipocyte size (Blouin et al. 2009; Semirale et al. 2011) by preventing the commitment of preadipocytes (Chazenbalk et al. 2013), promoting lipolysis (Blouin et al. 2009) and blocking preadipocyte proliferation (Fujioka et al. 2012). Androgens induce epidermal hyperplasia and affect the skin's barrier function (Kao et al. 2001). In the hair follicle, androgens play an important role in the regula- tion of hair growth, altering the duration of anagen and telogen phases of the hair follicle cycle. Androgens display pleiotrophic roles in humans depending on the region of skin. Androgens can promote hair follicle enlargement in some areas, mainly hair follicles associated with secondary sexual characteristics, while miniaturizing hair follicles in the scalp area (Rosenfield 2005). Whether a link exists, the role of androgen signaling in adipocyte regulation and regeneration of the hair follicle is now known.

Although the effects of estrogen and androgen are well characterized in the adipose depots, their role in the interplay between dermal adipocytes and the hair follicle and other cell types in the skin has not been explored to date. Of particular interest are specific roles of these systemic factors on dermal adipocytes and how alterations in dermal adipocytes by sex hormones can alter skin biology.

\section{POTENTIAL ADDITIONAL ROLES OF ADIPOCYTES IN THE SKIN}

One of the main roles of white adipocytes is the storage of fatty acids from the diet, which can be released and used for energy. Within adipocytes, the process of lipolysis hydrolyzes triglycerides into free FA, which can be transferred to surrounding cells (Zimmermann et al. 2004). Although keratinocytes can generate FA (Khnykin et al. 2011), dietary FAs are necessary for cutaneous biology and it is tempting to speculate that dermal adipocytes provide a local source of fatty acids within the skin. Two essential FAs that must be obtained from the diet, linoleic acid and $\alpha$-linoleic acid, and FAs found in fish oil, plants, or systemic delivery of labeled FAs, have been found in epidermal cells (Reynolds et al. 1978; Ziboh et al. 1986; Schürer et al. 1994). In addition, defects in FA transporters can lead to skin barrier defects in mice and ichthyosis in humans (Khnykin et al. 2011), supporting an essential role for fatty acids in skin function.

Many tissues can use FAs for energy by means of $\beta$-oxidation. Analysis of metabolic pathways in isolated hair follicles revealed that aerobic glucose oxidation rather than $\beta$-oxida- 
tion is predominantly used during follicular growth (Philpott and Kealey 1991). However, fatty acids can provide some energy to fuel hair follicle growth, suggesting that hair follicle cells are capable of $\beta$-oxidation. Moreover, Lcarnitine, an essential cofactor for $\beta$-oxidation, is capable of prolonging the growth stage of the hair follicle (Foitzik et al. 2007) and promotes skin wound healing (Pola et al. 1991). Additional evidence for the importance of fatty acid metabolism in the skin is the increased activity of the fatty acid enzyme CPT1 in psoriasis. Blocking CPT1 activity, key for $\beta$-oxidation, reduces keratinocyte differentiation and proliferation in psoriatic skin (Caspary et al. 2005). These findings support a role for fatty acid metabolism in fueling cellular processes in the skin and its appendages. Although recent reports implicate lipid metabolism in adult neural stem cell proliferation and hematopoietic stem cell maintenance, future studies are needed to determine whether lipid metabolism regulates cutaneous cell biology (Ito et al. 2012; Knobloch et al. 2013).

Another major role of WAT is the secretion of molecules called adipokines, which mediate autocrine or paracrine functions within adipose tissue or other tissues, respectively. Two of the main adipokines, leptin and adiponectin, are expressed by adipocytes and regulate food intake, metabolism, insulin resistance, and adipose tissue homeostasis (Lafontan 2012; Raucci et al. 2013). Dermal adipocytes express leptin (Murad et al. 2003) and the leptin receptor is expressed in both keratinocytes and dermal cells including the dermal papilla (Glasow et al. 2001; Iguchi et al. 2001; Stallmeyer et al. 2001; Takahashi et al. 2010). Leptin can stimulate keratinocyte proliferation and re-epithelialization of skin wounds (Frank et al. 2000; Shibata et al. 2012) and injection of antileptin antibodies into skin wounds reduced fibroblast function during healing (Murad et al. 2003). Although skin-associated adipocytes have been reported to express leptin, whether other cell types express leptin or systemic leptin from other adipocyte depots can affect skin biology is not known.

Adiponectin is a well-known adipokine with functional activity in the skin. Adiponectin is able to regulate growth and differentiation of the human keratinocyte cell line HaCaT, possibly through the regulation of TGF- $\beta$, which suggests that adiponectin may act during wound healing (Kawai et al. 2008). Supporting this theory, adiponectin can regulate the expression of several cytokines that activate the immune system (Takahashi et al. 2010) and can modulate keratinocyte proliferation and migration through the ERK signaling pathway (Shibata et al. 2012). Moreover, adiponectin receptors are expressed in cultured dermal cells (Akazawa et al. 2011) and adiponectin can promote hair growth in vitro (Won et al. 2012), hinting at the possibility that adiponectin derived from dermal adipocytes might also regulate hair follicle biology.

In addition to known adipokines, adipocytes are known to express other molecules that regulate cutaneous biology. IL-6, a well-known adipokine, is also expressed by epithelial cells in the skin, causing a thickening of the stratum corneum, whereas the differentiation program remained unaltered (Turksen et al. 1992). IL-6 knockout mice also displayed delayed hair growth and epidermal barrier defects (Wang et al. 2004). Adipocytes also express molecules such as nerve growth factor (NGF) and TGF- $\beta$ (Samad et al. 1997; Peeraully et al. 2004), which can have opposite effects in keratinocyte proliferation (Pietenpol et al. 1990; Paus et al. 1994). Insulin-like growth factor 1 (IGF-1), also produced by adipocytes, regulates the hair follicle cycle and keratinocyte differentiation (Weger and Schlake 2005; Sadagurski et al. 2006). Finally, basic fibroblast growth factor (bFGF) is involved in the regulation of adipogenesis (Neubauer et al. 2004) and can induce growth and migration of keratinocytes (Sogabe et al. 2006). Whether these molecules are expressed by dermal adipocytes to regulate skin function in the skin will be an area of intriguing investigation in the future.

\section{CUTANEOUS DISEASES ASSOCIATED WITH DEFECTS IN ADIPOCYTES}

Several conditions have been reported that alter skin-associated adipocytes in human patients. 
G. Rivera-Gonzalez et al.

Lipedematous scalp and lipedematous alopecia are rare disorders characterized by a thick and spongy scalp with dysfunction in skin associated adipose tissue, hyperkeratosis (Fukumoto et al. 2009), lymphocytic infiltrates (Bridges et al. 2000; Fiorenza et al. 2010) and androgenic alopecia (Piraccini et al. 2006). In addition, loss of adipocytes in lipodystrophic conditions has been associated with alopecia (Fig. 4) (Hegele et al. 2002; Hegele 2005; Agostini et al. 2006; Fukumoto et al. 2009; Jeninga et al. 2009). The most prevalent form of inherited partial lipodystrophy results from a mutation in the LMNA gene, encoding nuclear envelope proteins lamin A and C. Lamin A has been shown to influence adipocyte differentiation, potentially through PPAR $\gamma$ and insulin signaling
(Agostini et al. 2006; Boguslavsky et al. 2006). Individuals with mutations in the LMNA gene have been reported to have a variety of skin defects including mottled hypo- and hyperpigmentation, hair thinning and mild baldness, premature hair graying, sebaceous hyperplasia, and thin skin (Hegele 2005; Agostini et al. 2006; Garg et al. 2009; Patel et al. 2009). Whether these defects are caused by adipocyte defects or other defects in the skin epithelium is unknown.

In addition to LMNA mutations, familial partial lipodystrophy can occur from mutations in PPAR $\gamma$ (Moitra et al. 1998; Hegele et al. 2002; Hegele 2005; Agostini et al. 2006; Duan et al. 2007). As previously mentioned, PPAR $\gamma$ is critical for adipocyte differentiation and maintenance of mature adipocytes. Whereas many dif-
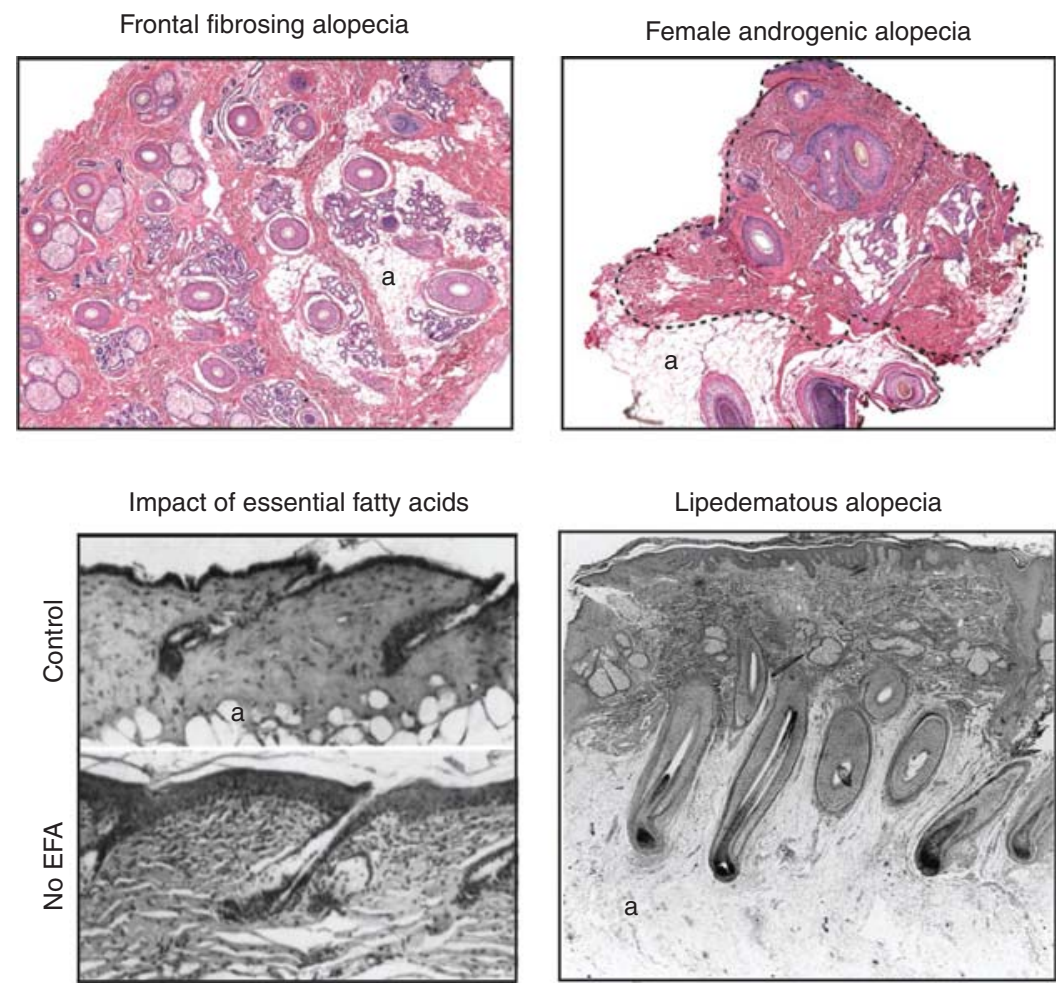

Figure 4. Cutaneous disorders with skin associated adipocyte defects. Frontal fibrosing alopecia and female androgenic alopecia are associated with changes in dermal composition including a loss of adipocytes in affected areas. Similarly, feeding mice a diet lacking essential fatty acids leads to dermal adipocyte loss, alopecia, and epidermal hyperplasia (Menton 1968). In contrast, patients with lipedematous alopecia display increased but defective skin-associated adipocytes (Fair et al. 2000). a, Dermal adipose tissue. (Images courtesy of Christine Ko; with permission from John Wiley and Sons.) 
ferent PPAR $\gamma$ mutations have been identified in humans, dysfunctional PPAR $\gamma$ is typically associated with a loss of adipose tissue and metabolic abnormalities (Okazawa et al. 1997; Jong et al. 1998; Savage et al. 2003). In addition to hyperpigmentation of the skin, similar to patients with LMNA mutations (Herrmann et al. 2003; Agostini et al. 2006), individuals with mutant PPAR $\gamma$ have hirsutism and cutaneous eruptive xanthomata (Hegele 2005; Agostini et al. 2006). Although it is unclear whether changes in skin biology are a direct result from the loss of adipose tissue, examining the role of dermal adipocytes in these pathologies will be an interesting avenue for future investigation.

A general loss of adipose tissue can also occur in starvation conditions such as anorexia, an eating disorder with a complex etiology. Alopecia, hair loss, and fragile hair are symptoms of anorexia in as many as $61 \%$ of patients and are the result of prolonged starvation (Strumia 2009). As expected, the fat depots in anorexics are extensively depleted and it is difficult to assess the contribution of this depletion to hair loss and alopecia. Because leptin levels are reduced in anorexia patients this could partially explain the defect in hair biology (Lord et al. 1998; Uzum et al. 2009; Janas-Kozik et al. 2011).

Accumulation of WAT in other depots during obesity can also influence skin-related disorders including psoriasis, ulceration, infection, and poor wound healing (Frank et al. 2000; Ryo et al. 2004; Yosipovitch et al. 2007; Guilherme et al. 2008; Shipman and Millington 2011). Whether changes in skin-associated adipose tissue contribute to these phenotypes is not well understood. Changes in visceral and subcutaneous adipose tissue occur during obesity include an altered adipokine production by adipocytes and increased infiltration of $\mathrm{T}$ cells and proinflammatory macrophages within adipose tissue (Lord et al. 1998; Skurk et al. 2007; Kintscher et al. 2008; Patsouris et al. 2008; Blüher 2009; Fernández-Riejos et al. 2010; Ouchi et al. 2011; Sun et al. 2011; Schipper et al. 2012; Deng et al. 2013). These changes in WAT inflammation are thought to arise from reduced adipocyte secretion of anti-inflammatory molecules such as adiponectin (Frank et al. 2000;
Wetzler et al. 2000; Ryo et al. 2004; Guilherme et al. 2008) and increased expression of proinflammatory factors (TNF- $\alpha$, IL-6, IL-18 restin, RBP4, and ANGPTL2), macrophage chemoattractants (MCP-1 and NAMPT), and leptin (Lord et al. 1998; Goren et al. 2003; FernándezRiejos et al. 2010; Ouchi et al. 2011). Given the importance of immune cells in wound healing and the pathogenesis of psoriasis, an altered interaction of adipocytes with immune cells may contribute to these skin-related disorders.

In addition to a potential local effect of skinassociated adipocytes in obesity, the development of insulin resistance and type II diabetes in obese individuals (Guilherme et al. 2008) can influence the function of skin cells. Some of the skin defects associated with diabetes have been attributed to keratinocyte dysfunction, caused by alterations in insulin signaling that alter the differentiation and motility of keratinocytes (Benoliel et al. 1997; Wertheimer et al. 2000). Several diabetic animal models have recapitulated some of the skin phenotypes of diabetic patients. Obese/obese (ob/ob) mice have a mutation in leptin, the $o b$ gene product, and show impaired wound healing resulting from a diabetic phenotype. Administration of leptin to $\mathrm{ob} / \mathrm{ob}$ mice rescues impaired re-epithelialization and accelerates wound healing in wildtype mice (Frank et al. 2000), possibly through regulating immune cell infiltration during the inflammatory phase of wound healing (Goren et al. 2003). Mice with a functional mutation in the leptin receptor ( $\mathrm{db} / \mathrm{db}$ mouse) also display a diabetic phenotype. These mice experience persistent inflammation (presence of neutrophils and macrophages and altered cytokine levels) during late phases of wound healing and contain dysfunctional $\gamma \delta$ T cells (Wetzler et al. 2000; Taylor et al. 2011). Db/db mice contain lower levels of keratinocyte growth factor (KGF) and temporally altered levels of acidic and basic FGF during wound healing (Werner et al. 1994).

Diabetic mice also display impaired fibroblast function that contributes to lower collagen concentrations and reduced skin tensile strength (Enser and Avery 1984). During wound healing, these mice have defects in collagen formation, which contribute to wound closure 
deficiencies (Goodson and Hunt 1979, 1986). A connection between adipocyte and fibroblast lineages has been suggested in skeletal muscle, where a common FAP may exist that can generate both fibroblasts and adipocytes (Joe et al. 2010; Uezumi et al. 2011). Given diversity that exists among fibroblasts (Werner et al. 2007), identification of the cell types that generate fibroblasts and adipocytes in the skin may reveal novel aspects of the pathogenesis of skin defects in obesity.

Fibroblast defects also occur in many human diseases in which skin-associated adipose tissue is lost, resulting in skin fibrosis and increased dermal collagen deposition (Smith and Chan 2010). Many factors are thought to influence the pathogenesis of skin fibrosis including autoimmunity, inflammation, fibroblast dysfunction, and vascularization. Given the potential lineage relationship and the interaction of adipocytes and fibroblasts in the skin during wound healing (Schmidt and Horsley 2013), it is possible that fibroblast defects during fibrosis may result from defects in the function of adipocyte precursor cells or a common FAP cell in the skin. Interestingly, histological analysis of frontal fibrosing alopecia suggests that adipocytes are lost where regions of fibrosis have occurred (Fig. 4). Thus, a switch in cell fate of an adipocyte or a putative FAP may contribute to the generation of more fibroblasts and reduced adipocytes during the pathogenesis of skin fibrosis. The identification and analysis of human adipocyte and fibroblast precursor cells in the skin may reveal their contribution to fibrotic disorders.

\section{CONCLUDING REMARKS}

Until recently, adipocytes were primarily considered mere reservoirs of energy stored as lipid. Deeper study of adipocyte biology in different anatomical locations has unveiled a plethora of roles in food-intake, diabetes, glucose resistance, and metabolism in general. However, adipocytes secrete many molecules that are known to regulate processes beyond metabolism. In the skin, their role in the regulation of hair follicle growth and skin epithelia in health and disease might be the first of many previously unknown roles of adipocyte lineage cells in the skin. Many key questions remain unanswered regarding adipocyte biology in the skin. We still need to understand the developmental origin of adipocytes and whether they have particular characteristics unique to the dermal depot. What are the molecular mechanisms that regulate dermal adipogenesis and promote the function of these cells in the skin during hair follicle growth, wound healing, and skin diseases? Understanding adipocyte behavior and how it affects the other cellular components in the skin will not only improve our knowledge of macroenvironment of skin tissue but may also be translated into new treatments for skin and hair folliclerelated diseases.

\section{ACKNOWLEDGMENTS}

We thank Dr. Christine Ko for providing images and Dr. Matthew Rodeheffer and Horsley laboratory members for critical reading of the manuscript and valuable discussions. V.H. is a Pew Scholar in Biomedical Research and is funded by the NIH (AR060295) and CT Innovations (12-SCB-YALE-01).

\section{REFERENCES}

Agostini M, Schoenmakers E, Mitchell C, Szatmari I, Savage D, Smith A, Rajanayagam O, Semple R, Luan J, Bath L, et al. 2006. Non-DNA binding, dominant-negative, human PPAR $\gamma$ mutations cause lipodystrophic insulin resistance. Cell Metab 4: 303-311.

Akazawa Y, Sayo T, Sugiyama Y, Sato T, Akimoto N, Ito A, Inoue S. 2011. Adiponectin resides in mouse skin and upregulates hyaluronan synthesis in dermal fibroblasts. Connect Tissue Res 52: 322-328.

Alexaki V-I, Simantiraki D, Panayiotopoulou M, Rasouli O, Venihaki M, Castana O, Alexakis D, Kampa M, Stathopoulos EN, Castanas E. 2012. Adipose tissue-derived mesenchymal cells support skin reepithelialization through secretion of KGF-1 and PDGF-BB: Comparison with dermal fibroblasts. Cell Transplant 21: 2441-2454.

Ashcroft GS, Horan MA, Ferguson MW. 1997. Aging is associated with reduced deposition of specific extracellular matrix components, an upregulation of angiogenesis, and an altered inflammatory response in a murine incisional wound healing model. J Invest Dermatol 108: 430437.

Ashcroft GS, Mills SJ, Lei K, Gibbons L, Jeong M-J, Taniguchi M, Burow M, Horan MA, Wahl SM, Nakayama T. 2003. Estrogen modulates cutaneous wound healing by 
downregulating macrophage migration inhibitory factor. J Clin Invest 111: 1309-1318.

Benoliel AM, Kahn-Perles B, Imbert J, Verrando P. 1997. Insulin stimulates haptotactic migration of human epidermal keratinocytes through activation of NF- $\mathrm{\kappa B}$ transcription factor. J Cell Sci 110: 2089-2097.

Berry R, Rodeheffer MS. 2013. Characterization of the adipocyte cellular lineage in vivo. Nat Cell Biol 15:302-308

Bilkei-Gorzo A, Drews E, Albayram Ö, Piyanova A, Gaffal E, Tueting T, Michel K, Mauer D, Maier W, Zimmer A. 2012. Early onset of aging-like changes is restricted to cognitive abilities and skin structure in $\mathrm{Cnrl}^{-/-}$mice. Neurobiol Aging 33: 200.e11-22.

Blanpain C, Lowry WE, Geoghegan A, Polak L, Fuchs E. 2004. Self-renewal, multipotency, and the existence of two cell populations within an epithelial stem cell niche. Cell 118: 635-648.

Blouin K, Veilleux A, Luu-The V, Tchernof A. 2009. Androgen metabolism in adipose tissue: Recent advances. $\mathrm{Mol}$ Cell Endocrinol 301: 97-103.

Blüher M. 2009. Adipose tissue dysfunction in obesity. Exp Clin Endocrinol Diabetes 117: 241-250.

Boguslavsky RL, Stewart CL, Worman HJ. 2006. Nuclear lamin A inhibits adipocyte differentiation: Implications for Dunnigan-type familial partial lipodystrophy. Hum Mol Genet 15: 653-663.

Bridges AG, Kuster von LC, Estes SA. 2000. Lipedematous alopecia. Cutis 65: 199-202

Carmean CM, Cohen RN, Brady MJ. 2013. Systemic regulation of adipose metabolism. Biochim Biophys Acta doi: 10.1016/j.bbadis.2013.06.004.

Cartwright MJ, Schlauch K, Lenburg ME, Tchkonia T, Pirtskhalava T, Cartwright A, Thomou T, Kirkland JL. 2010. Aging, depot origin, and preadipocyte gene expression. J Gerontol A Biol Sci Med Sci 65: 242-251.

Caspary F, Elliott G, Navé BT, Verzaal P, Rohrbach M, Das PK, Nagelkerken L, Nieland JD. 2005. A new therapeutic approach to treat psoriasis by inhibition of fatty acid oxidation by Etomoxir. Br J Dermatol 153: 937-944.

Chanda S, Robinette CL, Couse JF, Smart RC. 2000. 17ßEstradiol and ICI-182780 regulate the hair follicle cycle in mice through an estrogen receptor- $\alpha$ pathway. Am J Physiol Endocrinol Metab 278: E202-E210.

Chase HB, Montagna W, Malone JD. 1953. Changes in the skin in relation to the hair growth cycle. Anat Rec 116: $75-81$.

Chazenbalk G, Singh P, Irge D, Shah A, Abbott DH, Dumesic DA. 2013. Androgens inhibit adipogenesis during human adipose stem cell commitment to preadipocyte formation. Steroids 78: 920-926.

Chen HC, Smith SJ, Tow B, Elias PM, Farese RV. 2002. Leptin modulates the effects of acyl CoA:diacylglycerol acyltransferase deficiency on murine fur and sebaceous glands. J Clin Invest 109: 175-181.

Christodoulides C, Lagathu C, Sethi JK, Vidal-Puig A. 2009. Adipogenesis and WNT signalling. Trends Endocrinol Metab 20: 16-24.

Collins CA, Kretzschmar K, Watt FM. 2011. Reprogramming adult dermis to a neonatal state through epidermal activation of $\beta$-catenin. Development 138: 5189-5199.
Cooke PS, Heine PA, Taylor JA, Lubahn DB. 2001. The role of estrogen and estrogen receptor- $\alpha$ in male adipose tissue. Mol Cell Endocrinol 178: 147-154.

Cotsarelis G, Sun TT, Lavker RM. 1990. Label-retaining cells reside in the bulge area of pilosebaceous unit: Implications for follicular stem cells, hair cycle, and skin carcinogenesis. Cell 61: 1329-1337.

Courtois M, Loussouarn G, Hourseau C, Grollier JF. 1995. Ageing and hair cycles. Br J Dermatol 132: 86-93.

Delavary BM, van der Veer WM, van Egmond M, Niessen FB, Beelen RHJ. 2011. Macrophages in skin injury and repair. Immunobiology 216: 753-762.

Deng T, Lyon CJ, Minze LJ, Lin J, Zou J, Liu JZ, Ren Y, Yin Z, Hamilton DJ, Reardon PR, et al. 2013. Class II major histocompatibility complex plays an essential role in obesity-induced adipose inflammation. Cell Metab 17: 411-422.

Deplewski D, Rosenfield RL. 2000. Role of hormones in pilosebaceous unit development. Endocr Rev 21: $363-$ 392.

de Rycker C, Vandalem JL, Hennen G. 1984. Effects of 3,5,3'triiodothyronine on collagen synthesis by cultured human skin fibroblasts. FEBS Lett 174: 34-37.

Djian P, Roncari AK, Hollenberg CH. 1983. Influence of anatomic site and age on the replication and differentiation of rat adipocyte precursors in culture. J Clin Invest 72: $1200-1208$.

Doles J, Storer M, Cozzuto L, Roma G, Keyes WM. 2012. Age-associated inflammation inhibits epidermal stem cell function. Genes Dev 26: 2144-2153.

Duan SZ, Ivashchenko CY, Whitesall SE, D’Alecy LG, Duquaine DC, Brosius FC, Gonzalez FJ, Vinson C, Pierre MA, Milstone DS, et al. 2007. Hypotension, lipodystrophy, and insulin resistance in generalized PPAR $\gamma$-deficient mice rescued from embryonic lethality. J Clin Invest 117: 812-822.

Enser M, Avery NC. 1984. Mechanical and chemical properties of the skin and its collagen from lean and obesehyperglycaemic (ob/ob) mice. Diabetologia 27: 44-49.

Enshell-Seijffers D, Lindon C, Kashiwagi M, Morgan BA. 2010. $\beta$-catenin activity in the dermal papilla regulates morphogenesis and regeneration of hair. Dev Cell 18: 633-642.

Fain JN, Ihle JH, Bahouth SW. 1999. Stimulation of lipolysis but not of leptin release by growth hormone is abolished in adipose tissue from stat5a and $\mathrm{b}$ knockout mice. Biochem Biophys Res Commun 263: 201-205.

Fair KP, Knoell KA, Patterson JW, Rudd RJ, Greer KE. 2000. Lipedematous alopecia: A clinicopathologic, histologic and ultrastructural study. J Cutan Pathol 27: 49-53.

Fernández-Riejos P, Najib S, Santos-Alvarez J, Martín-Romero C, Pérez-Pérez A, González-Yanes C, Sánchez-Margalet V. 2010. Role of leptin in the activation of immune cells. Mediators Inflamm 2010: 568343.

Festa E, Fretz J, Berry R, Schmidt B, Rodeheffer M, Horowitz M, Horsley V. 2011. Adipocyte lineage cells contribute to the skin stem cell niche to drive hair cycling. Cell 146: 761-771.

Fiorenza CG, Chou SH, Mantzoros CS. 2010. Lipodystrophy: Pathophysiology and advances in treatment. Nature 7: $137-150$ 


\section{G. Rivera-Gonzalez et al.}

Foitzik K, Hoting E, Förster T, Pertile P, Paus R. 2007. LCarnitine-L-tartrate promotes human hair growth in vitro. Exp Dermatol 16: 936-945.

Forcheron F, Agay D, Scherthan H, Riccobono D, Herodin F, Meineke V, Drouet M. 2012. Autologous adipocyte derived stem cells favour healing in a minipig model of cutaneous radiation syndrome. PLoS ONE 7: e31694.

Frank S, Stallmeyer B, Kämpfer H, Kolb N, Pfeilschifter J. 2000. Leptin enhances wound re-epithelialization and constitutes a direct function of leptin in skin repair. $J$ Clin Invest 106: 501-509.

Fujioka K, Kajita K, Wu Z, Hanamoto T, Ikeda T, Mori I, Okada H, Yamauchi M, Uno Y, Morita H, et al. 2012. Dehydroepiandrosterone reduces preadipocyte proliferation via androgen receptor. Am J Physiol Endocrinol Metab 302: E694-E704.

Fukumoto D, Kubo Y, Saito M, Arase S. 2009. Centrifugal lipodystrophy of the scalp presenting with an arch-form alopecia: A 10-year follow-up observation. J Dermatol 36: 499-503.

Garg A, Subramanyam L, Agarwal AK, Simha V, Levine B, D'Apice MR, Novelli G, Crow Y. 2009. Atypical progeroid syndrome due to heterozygous missense LMNA mutations. 94: 4971-4983.

Gesta S. 2006. Evidence for a role of developmental genes in the origin of obesity and body fat distribution. Proc Natl Acad Sci 103: 6676-6681.

Gesta S, Tseng Y-H, Kahn CR. 2007. Developmental origin of fat: Tracking obesity to its source. Cell 131: 242-256.

Geyfman M, Andersen B. 2010. Clock genes, hair growth and aging. Aging (Albany NY) 2: 122-128.

Giangreco A, Qin M, Pintar JE, Watt FM. 2008. Epidermal stem cells are retained in vivo throughout skin aging. Aging Cell 7: 250-259.

Glasow A, Kiess W, Anderegg U, Berthold A, Bottner A, Kratzsch J. 2001. Expression of leptin (Ob) and leptin receptor (Ob-R) in human fibroblasts: Regulation of leptin secretion by insulin. J Clin Endocrinol Metab 86: 4472-4479.

Goodson WH, Hunt TK. 1979. Deficient collagen formation by obese mice in a standard wound model. Am J Surg 138: 692-694.

Goodson WH, Hunt TK. 1986. Wound collagen accumulation in obese hyperglycemic mice. Diabetes 35: 491-495.

Goren I, Kämpfer H, Podda M, Pfeilschifter J, Frank S. 2003. Leptin and wound inflammation in diabetic ob/ob mice: Differential regulation of neutrophil and macrophage influx and a potential role for the scab as a sink for inflammatory cells and mediators. Diabetes 52: 2821-2832.

Gosain A, DiPietro LA. 2004. Aging and wound healing. World J Surg 28: 321-326.

Greco V, Chen T, Rendl M, Schober M, Pasolli HA, Stokes N, Cruz-Racelis Dela J, Fuchs E. 2009. A two-step mechanism for stem cell activation during hair regeneration. Cell Stem Cell 4: 155-169.

Grove GL, Kligman AM. 1983. Age-associated changes in human epidermal cell renewal. J Gerontol 38: 137-142.

Guilherme A, Virbasius JV, Puri V, Czech MP. 2008. Adipocyte dysfunctions linking obesity to insulin resistance and type 2 diabetes. Nat Rev Mol Cell Biol 9: 367-377.
Hale PA, Ebling FJ. 1979. The effect of a single epilation on successive hair eruptions in normal and hormone-treated rats. J Exp Zool 207: 49-71.

Harrison DE, Archer JR. 1988. Biomarkers of aging: Tissue markers. Future research needs, strategies, directions and priorities. Exp Gerontol 23: 309-325.

Hausman GJ, Campion DR, Richardson RL, Martin RJ. 1981. Adipocyte development in the rat hypodermis. Am J Anat 161: 85-100.

Hegele RA. 2005. Lessons from human mutations in PPAR $\gamma$. Int J Obes 29: S31-S35.

Hegele RA, Cao H, Frankowski C, Mathews ST, Leff T. 2002. PPARG F388L, a transactivation-deficient mutant, in familial partial lipodystrophy. Diabetes 51: 3586-3590.

Heine PA, Taylor JA, Iwamoto GA, Lubahn DB, Cooke PS. 2000. Increased adipose tissue in male and female estrogen receptor- $\alpha$ knockout mice. Proc Natl Acad Sci 97: 12729-12734.

Herrmann T, van der Hoeven F, Grone H-J, Stewart AF, Langbein L, Kaiser I, Liebisch G, Gosch I, Buchkremer F, Drobnik W, et al. 2003. Mice with targeted disruption of the fatty acid transport protein 4 (Fatp 4, Slc27a4) gene show features of lethal restrictive dermopathy. J Cell Biol 161: 1105-1115.

Hu H-M, Zhang S-B, Lei X-H, Deng Z-L, Guo W-X, Qiu ZF, Liu S, Wang X-Y, Zhang H, Duan E-K. 2012. Estrogen leads to reversible hair cycle retardation through inducing premature catagen and maintaining telogen. PLoS ONE 7: e40124.

Huang H, Song T-J, Li X, Hu L, He Q, Liu M, Lane MD, Tang QQ. 2009. BMP signaling pathway is required for commitment of C3H10T1/2 pluripotent stem cells to the adipocyte lineage. Proc Natl Acad Sci 106: 12670-12675.

Huang S-P, Hsu C-C, Chang S-C, Wang C-H, Deng S-C, Dai N-T, Chen T-M, Chan JY-H, Chen S-G, Huang S-M. 2012. Adipose-derived stem cells seeded on acellular dermal matrix grafts enhance wound healing in a murine model of a full-thickness defect. Ann Plastic Surg 69: 656-662.

Iguchi M, Aiba S, Yoshino Y, Tagami H. 2001. Human follicular papilla cells carry out nonadipose tissue production of leptin. J Invest Dermatol 117: 1349-1356.

Ito K, Carracedo A, Weiss D, Arai F, Ala U, Avigan DE, Schafer ZT, Evans RM, Suda T, Lee C-H, et al. 2012. A PML-PPAR- $\delta$ pathway for fatty acid oxidation regulates hematopoietic stem cell maintenance. Nat Med 18: 1350-1358.

Jackson WM, Nesti LJ, Tuan RS. 2012. Concise review: Clinical translation of wound healing therapies based on mesenchymal stem cells. Stem Cells Transl Med 1: 44-50.

Jahoda CA, Horne KA, Oliver RF. 1984. Induction of hair growth by implantation of cultured dermal papilla cells. Nature 311: 560-562.

Janas-Kozik M, Stachowicz M, Krupka-Matuszczyk I, Szymszal J, Krysta K, Janas A, Rybakowski JK. 2011. Plasma levels of leptin and orexin $A$ in the restrictive type of anorexia nervosa. Regul Pept 168: 5-9.

Jeninga EH, Gurnell M, Kalkhoven E. 2009. Functional implications of genetic variation in human PPAR $\gamma$. Trends Endocrinol Metab 20: 380-387. 
Jiang D, Qi Y, Walker NG, Sindrilaru A, Hainzl A, Wlaschek M, MacNeil S, Scharffetter-Kochanek K. 2013. The effect of adipose tissue derived MSCs delivered by a chemically defined carrier on full-thickness cutaneous wound healing. Biomaterials 34: 2501-2515.

Joe AWB, Yi L, Even Y, Vogl AW, Rossi FMV. 2009. Depotspecific differences in adipogenic progenitor abundance and proliferative response to high-fat diet. Stem Cells 27: 2563-2570.

Joe AWB, Yi L, Natarajan A, Le Grand F, So L, Wang J, Rudnicki MA, Rossi FMV. 2010. Muscle injury activates resident fibro/adipogenic progenitors that facilitate myogenesis. Nat Cell Biol 12: 153-163.

Jong MC, Gijbels MJ, Dahlmans VE, Gorp PJ, Koopman SJ, Ponec M, Hofker MH, Havekes LM. 1998. Hyperlipidemia and cutaneous abnormalities in transgenic mice overexpressing human apolipoprotein C1. J Clin Invest 101: $145-152$.

Kanneganti T-D, Dixit VD. 2012. Immunological complications of obesity. Nat Immunol 13: 707-712.

Kao JS, Garg A, Mao-Qiang M, Crumrine D, Ghadially R, Feingold KR, Elias PM. 2001. Testosterone perturbs epidermal permeability barrier homeostasis. J Invest Dermatol 116: 443-451.

Karlsson LL, Bondjers CC, Betsholtz CC. 1999. Roles for PDGF-A and sonic hedgehog in development of mesenchymal components of the hair follicle. Development 126: $2611-2621$.

Kawai K, Kageyama A, Tsumano T, Nishimoto S, Fukuda K, Yokoyama S, Oguma T, Fujita K, Yoshimoto S, Yanai A, et al. 2008. Effects of adiponectin on growth and differentiation of human keratinocytes-implication of impaired wound healing in diabetes. Biochem Biophys Res Commun 374: $269-273$.

Khavkin J, Ellis DAF. 2011. Aging skin: Histology, physiology, and pathology. Facial Plast Surg Clin North Am 19: 229-234.

Khnykin D, Miner JH, Jahnsen F. 2011. Role of fatty acid transporters in epidermis: Implications for health and disease. Dermatoendocrinol 3: 53-61.

Kintscher U, Hartge M, Hess K, Foryst-Ludwig A, Clemenz M, Wabitsch M, Fischer-Posovszky P, Barth TFE, Dragun $\mathrm{D}$, Skurk T, et al. 2008. T-lymphocyte infiltration in visceral adipose tissue: A primary event in adipose tissue inflammation and the development of obesity-mediated insulin resistance. Arterioscler Thromb Vasc Biol 28 1304-1310.

Kirkland JL, Hollenberg CH, Gillon WS. 1990. Age, anatomic site, and the replication and differentiation of adipocyte precursors. Am J Physiol 258: C206-C210.

Knobloch M, Braun SMG, Zurkirchen L, Schoultz von C, Zamboni N, Araúzo-Bravo MJ, Kovacs WJ, Karalay O, Suter U, Machado RAC, et al. 2013. Metabolic control of adult neural stem cell activity by Fasn-dependent lipogenesis. Nature 493: 226-230.

Kobielak K, Stokes N, la Cruz de J, Polak L, Fuchs E. 2007. Loss of a quiescent niche but not follicle stem cells in the absence of bone morphogenetic protein signaling. Proc Natl Acad Sci 104: 10063-10068.

Kondratov RV, Kondratova AA, Gorbacheva VY, Vykhovanets OV, Antoch MP. 2006. Early aging and age-related pathologies in mice deficient in BMAL1, the core component of the circadian clock. Genes Dev 20: 1868-1873.

Konno M, Hamabe A, Hasegawa S, Ogawa H, Fukusumi T, Nishikawa S, Ohta K, Kano Y, Ozaki M, Noguchi Y, et al. 2013. Adipose-derived mesenchymal stem cells and regenerative medicine. Develop Growth Differ 55: 309-318.

Kuk JL, Saunders TJ, Davidson LE, Ross R. 2009. Age-related changes in total and regional fat distribution. Ageing Res Rev 8: 339-348.

Lafontan M. 2012. Historical perspectives in fat cell biology: The fat cell as a model for the investigation of hormonal and metabolic pathways. Am J Physiol Cell Physiol 302: C327-C359.

Le Douarin NM. 2004. The avian embryo as a model to study the development of the neural crest: A long and still ongoing story. Mech Dev 121: 1089-1102.

Lee Y-H, Petkova AP, Mottillo EP, Granneman JG. 2012. In vivo identification of bipotential adipocyte progenitors recruited by $\beta 3$-adrenoceptor activation and high-fat feeding. Cell Metab 15: 480-491.

Lord GM, Matarese G, Howard JK, Baker RJ, Bloom SR, Lechler RI. 1998. Leptin modulates the T-cell immune response and reverses starvation-induced immunosuppression. Nature 394: 897-901.

Luo Y, Toyoda M, Nakamura M, Morohashi M. 2002. Morphological analysis of skin in senescence-accelerated mouse P10. Med Electron Microsc 35: 31-45.

Maklad A, Nicolai JR, Bichsel KJ, Evenson JE, Lee T-C, Threadgill DW, Hansen LA. 2009. The EGFR is required for proper innervation to the skin. J Invest Dermatol 129: 690-698.

Menton DN. 1968. The effects of essential fatty acid deficiency on the skin of the mouse. Am J Anat 122: 337-355.

Millar SE. 2006. Smad7: Licensed to kill $\beta$-catenin. Dev Cell 11: $274-276$

Mishra A, Zhu X-G, Ge K, Cheng S-Y. 2010. Adipogenesis is differentially impaired by thyroid hormone receptor mutant isoforms. J Mol Endocrinol 44: 247-255.

Moitra J, Mason MM, Olive M, Krylov D, Gavrilova O, Marcus-Samuels B, Feigenbaum L, Lee E, Aoyama T, Eckhaus M, et al. 1998. Life without white fat: A transgenic mouse. Genes Dev 12: 3168-3181.

Moller L, Dalman L, Norrelund H, Billestrup N, Frystyk J, Moller N, Jorgensen JOL. 2009. Impact of fasting on growth hormone signaling and action in muscle and fat. J Clin Endocrinol Metab 94: 965-972.

Morrison RF, Farmer SR. 1999. Role of PPAR $\gamma$ in regulating a cascade expression of cyclin-dependent kinase inhibitors, p18(INK4c) and p21(Waf1/Cip1), during adipogenesis. J Biol Chem 274: 17088-17097.

Murad A, Nath AK, Cha S-T, Demir E, Flores-Riveros J, Sierra-Honigmann MR. 2003. Leptin is an autocrine/ paracrine regulator of wound healing. FASEB $J$ 17: $1895-1897$.

Murata Y, Ceccarelli P, Refetoff S, Horwitz AL, Matsui N. 1987. Thyroid hormone inhibits fibronectin synthesis by cultured human skin fibroblasts. J Clin Endocrinol Metab 64: 334-339.

Neubauer M, Fischbach C, Bauer-Kreisel P, Lieb E, Hacker M, Tessmar J, Schulz MB, Goepferich A, Blunk T. 2004 Basic fibroblast growth factor enhances PPAR $\gamma$ ligand- 


\section{G. Rivera-Gonzalez et al.}

induced adipogenesis of mesenchymal stem cells. FEBS Lett 577: 277-283.

Oishi Y, Manabe I, Tobe K, Tsushima K, Shindo T, Fujiu K, Nishimura G, Maemura K, Yamauchi T, Kubota N, et al. 2005. Krüppel-like transcription factor KLF5 is a key regulator of adipocyte differentiation. Cell Metab 1:27-39.

Okazawa H, Mori H, Tamori Y, Araki S, Niki T, Masugi J, Kawanishi M, Kubota T, Shinoda H, Kasuga M. 1997. No coding mutations are detected in the peroxisome proliferator-activated receptor- $\gamma$ gene in Japanese patients with lipoatrophic diabetes. Diabetes 46: 1904-1906.

Ouchi N, Parker JL, Lugus JJ, Walsh K. 2011. Adipokines in inflammation and metabolic disease. Nat Rev Immuno 11: 85-97.

Patel K, Roseman D, Burbank H, Attarian H. 2009. Obstructive sleep apnea in familial partial lipodystrophy type 2 with atypical skin findings and vascular disease. Sleep Breath 13: 425-427.

Patsouris D, Li P-P, Thapar D, Chapman J, Olefsky JM, Neels JG. 2008. Ablation of CD11c-positive cells normalizes insulin sensitivity in obese insulin resistant animals. Cell Metab 8: 301-309.

Paus R, Lüftl M, Czarnetzki BM. 1994. Nerve growth factor modulates keratinocyte proliferation in murine skin organ culture. Br J Dermatol 130: 174-180.

Peeraully MR, Jenkins JR, Trayhurn P. 2004. NGF gene expression and secretion in white adipose tissue: Regulation in 3T3-L1 adipocytes by hormones and inflammatory cytokines. Am J Physiol Endocrinol Metab 287: E331E339.

Penza M, Montani C, Romani A, Vignolini P, Pampaloni B, Tanini A, Brandi ML, Alonso-Magdalena P, Nadal A, Ottobrini L, et al. 2006. Genistein affects adipose tissue deposition in a dose-dependent and gender-specific manner. Endocrinology 147: 5740-5751.

Philpott MP, Kealey T. 1991. Metabolic studies on isolated hair follicles: Hair follicles engage in aerobic glycolysis and do not demonstrate the glucose fatty acid cycle. J Invest Dermatol 96: 875-879.

Pietenpol JA, Holt JT, Stein RW, Moses HL. 1990. Transforming growth factor $\beta 1$ suppression of c-myc gene transcription: Role in inhibition of keratinocyte proliferation. Proc Natl Acad Sci 87: 3758-3762.

Piraccini BM, Voudouris S, Pazzaglia M, Rech G, Vicenzi C, Tosti A. 2006. Lipedematous alopecia of the scalp. Dermatol Online J 12: 6.

Plikus MV, Mayer JA, la Cruz de D, Baker RE, Maini PK, Maxson R, Chuong C-M. 2008. Cyclic dermal BMP signalling regulates stem cell activation during hair regeneration. Nature 451: 340-344.

Pola P, Flore R, Serricchio M, Tondi P. 1991. New carnitine derivatives for the therapy of cutaneous ulcers in vasculopathics. Drugs Exp Clin Res 17: 277-282.

Puolakkainen PA, Twardzik DR, Ranchalis JE, Pankey SC, Reed MJ, Gombotz WR. 1995. The enhancement in wound healing by transforming growth factor $\beta 1$ (TGF- $\beta 1$ ) depends on the topical delivery system. J Surg Res 58: 321-329.

Raucci R, Rusolo F, Sharma A, Colonna G, Castello G, Costantini S. 2013. Functional and structural features of adipokine family. Cytokine 61: 1-14.
Reed MJ, Ferara NS, Vernon RB. 2001. Impaired migration, integrin function, and actin cytoskeletal organization in dermal fibroblasts from a subset of aged human donors Mech Ageing Dev 122: 1203-1220.

Rendl M, Lewis L, Fuchs E. 2005. Molecular dissection of mesenchymal-epithelial interactions in the hair follicle. PLoS Biol 3: e331.

Rendl M, Polak L, Fuchs E. 2008. BMP signaling in dermal papilla cells is required for their hair follicle-inductive properties. Genes Dev 22: 543-557.

Reynolds DJ, Marks R, Davies MG, Dykes PJ. 1978. The fatty acid composition of skin and plasma lipids in Refsum's disease. Clin Chim Acta 90: 171-177.

Riccobono D, Agay D, Scherthan H, Forcheron F, Vivier M, Ballester B, Meineke V, Drouet M. 2012. Application of adipocyte-derived stem cells in treatment of cutaneous radiation syndrome. Health Phys 103: 120-126.

Rodeheffer MS, Birsoy K, Friedman JM. 2008. Identification of white adipocyte progenitor cells in vivo. Cell 135: 240-249.

Rogers J, Harding C, Mayo A, Banks J, Rawlings A. 1996. Stratum corneum lipids: The effect of ageing and the seasons. Arch Dermatol Res 288: 765-770.

Rompolas P, Deschene ER, Zito G, Gonzalez DG, Saotome I, Haberman AM, Greco V. 2012. Live imaging of stem cell and progeny behaviour in physiological hair-follicle regeneration. Nature 487: 496-499.

Rosen ED, Spiegelman BM. 2006. Adipocytes as regulators of energy balance and glucose homeostasis. Nature 444: 847-853.

Rosenfield RL. 2005. Hirsutism and the variable response of the pilosebaceous unit to androgen. J Investig Dermatol Symp Proc 10: 205-208.

Ross SE, Hemati N, Longo KA, Bennett CN, Lucas PC, Erickson RL, MacDougald OA. 2000. Inhibition of adipogenesis by Wnt signaling. Science 289: 950-953.

Ryo M, Nakamura T, Kihara S, Kumada M, Shibazaki S, Takahashi M, Nagai M, Matsuzawa Y, Funahashi T. 2004. Adiponectin as a biomarker of the metabolic syndrome. Circ J 68: 975-981.

Sadagurski M, Yakar S, Weingarten G, Holzenberger M, Rhodes CJ, Breitkreutz D, Leroith D, Wertheimer E. 2006. Insulin-like growth factor 1 receptor signaling regulates skin development and inhibits skin keratinocyte differentiation. Mol Cell Biol 26: 2675-2687.

Safer JD. 2011. Thyroid hormone action on skin. Dermatoendocrinol 3: 211-215.

Safer JD, Fraser LM, Ray S, Holick MF. 2001. Topical triiodothyronine stimulates epidermal proliferation, dermal thickening, and hair growth in mice and rats. Thyroid 11: 717-724.

Safer JD, Crawford TM, Fraser LM, Hoa M, Ray S, Chen TC, Persons K, Holick MF. 2003. Thyroid hormone action on skin: Diverging effects of topical versus intraperitoneal administration. Thyroid 13: 159-165.

Samad F, Yamamoto K, Pandey M, Loskutoff DJ. 1997. Elevated expression of transforming growth factor- $\beta$ in adipose tissue from obese mice. Mol Med 3: 37-48.

Savage DB, Tan GD, Acerini CL, Jebb SA, Agostini M, Gurnell M, Williams RL, Umpleby AM, Thomas EL, Bell JD, et al. 2003. Human metabolic syndrome resulting from 
dominant-negative mutations in the nuclear receptor peroxisome proliferator-activated receptor- $\gamma$. Diabetes 52: $910-917$.

Schipper BM, Marra KG, Zhang W, Donnenberg AD, Rubin JP. 2008. Regional anatomic and age effects on cell function of human adipose-derived stem cells. Ann Plastic Surg 60: 538-544.

Schipper HS, Prakken B, Kalkhoven E, Boes M. 2012. Adipose tissue-resident immune cells: Key players in immunometabolism. Trends Endocrinol Metabol 23: 407-415.

Schmidt BA, Horsley V. 2013. Intradermal adipocytes mediate fibroblast recruitment during skin wound healing. Development 140: 1517-1527.

Schürer NY, Stremmel W, Grundmann JU, Schliep V, Kleinert H, Bass NM, Williams ML. 1994. Evidence for a novel keratinocyte fatty acid uptake mechanism with preference for linoleic acid: Comparison of oleic and linoleic acid uptake by cultured human keratinocytes, fibroblasts and a human hepatoma cell line. Biochim Biophys Acta 1211: 51-60.

Semirale AA, Zhang X-W, Wiren KM. 2011. Body composition changes and inhibition of fat development in vivo implicates androgen in regulation of stem cell lineage allocation. J Cell Biochem 112: 1773-1786.

Shibata S, Tada Y, Asano Y, Hau CS, Kato T, Saeki H, Yamauchi T, Kubota N, Kadowaki T, Sato S. 2012. Adiponectin regulates cutaneous wound healing by promoting keratinocyte proliferation and migration via the ERK signaling pathway. J Immunol 189: 3231-3241.

Shipman AR, Millington GWM. 2011. Obesity and the skin. Br J Dermatol 165: 743-750.

Skurk T, Alberti-Huber C, Herder C, Hauner H. 2007. Relationship between adipocyte size and adipokine expression and secretion. J Clin Endocrinol Metabol 92: 10231033.

Smith GP, Chan ESL. 2010. Molecular pathogenesis of skin fibrosis: Insight from animal models. Curr Rheumatol Rep 12: 26-33.

Sogabe Y, Abe M, Yokoyama Y, Ishikawa O. 2006. Basic fibroblast growth factor stimulates human keratinocyte motility by Rac activation. Wound Repair Regen 14: 457-462.

Spalding KL, Arner E, Westermark PO, Bernard S, Buchholz BA, Bergmann O, Blomqvist L, Hoffstedt J, Näslund E, Britton T, et al. 2008. Dynamics of fat cell turnover in humans. Nature 453: 783-787.

Spinella-Jaegle S, Rawadi G, Kawai S, Gallea S, Faucheu C, Mollat P, Courtois B, Bergaud B, Ramez V, Blanchet AM, et al. 2001. Sonic hedgehog increases the commitment of pluripotent mesenchymal cells into the osteoblastic lineage and abolishes adipocytic differentiation. J Cell Sci 114: $2085-2094$.

Stallmeyer B, Kämpfer H, Podda M, Kaufmann R, Pfeilschifter J, Frank S. 2001. A novel keratinocyte mitogen: Regulation of leptin and its functional receptor in skin repair. J Invest Dermatol 117: 98-105.

Stone SJ, Myers HM, Watkins SM, Brown BE, Feingold KR, Elias PM, Farese RV. 2004. Lipopenia and skin barrier abnormalities in DGAT2-deficient mice. J Biol Chem 279: $11767-11776$.

Strumia R. 2009. Skin signs in anorexia nervosa. Dermatoendocrinol 1: 268-270.
Sun L-Q, Lee DW, Zhang Q, Xiao W, Raabe EH, Meeker A, Miao D, Huso DL, Arceci RJ. 2004. Growth retardation and premature aging phenotypes in mice with disruption of the SNF2-like gene, PASG. Genes Dev 18: 1035-1046.

Sun K, Kusminski CM, Scherer PE. 2011. Adipose tissue remodeling and obesity. J Clin Invest 121: 2094-2101.

Swift ME, Kleinman HK, DiPietro LA. 1999. Impaired wound repair and delayed angiogenesis in aged mice. Lab Invest 79: 1479-1487.

Takahashi H, Honma M, Ishida-Yamamoto A, Iizuka $\mathrm{H}$. 2010. Adiponectin and leptin modulate cell proliferation and cytokine secretion of normal human keratinocytes and T lymphocytes. J Dermatol Sci 59: 143-145.

Tang QQ, Otto TC, Lane MD. 2003. CCAAT/enhancerbinding protein $\beta$ is required for mitotic clonal expansion during adipogenesis. Proc Natl Acad Sci 100: 850 855.

Taylor KR, Costanzo AE, Jameson JM. 2011. Dysfunctional $\gamma \delta$ T cells contribute to impaired keratinocyte homeostasis in mouse models of obesity. J Invest Dermatol 131: 2409-2418.

Tchkonia T, Morbeck DE, Zglinicki Von T, Van Deursen J, Lustgarten J, Scrable H, Khosla S, Jensen MD, Kirkland JL. 2010. Fat tissue, aging, and cellular senescence. Aging Cell 9: 667-684.

Thiers BH, Maize JC, Spicer SS, Cantor AB. 1984. The effect of aging and chronic sun exposure on human Langerhans cell populations. J Invest Dermatol 82: 223-226.

Tontonoz P, Hu E, Spiegelman BM. 1994. Stimulation of adipogenesis in fibroblasts by PPAR $\gamma 2$, a lipid-activated transcription factor. Cell 79: 1147-1156.

Treiber N, Maity P, Singh K, Kohn M, Keist AF, Ferchiu F, Sante L, Frese S, Bloch W, Kreppel F, et al. 2011. Accelerated aging phenotype in mice with conditional deficiency for mitochondrial superoxide dismutase in the connective tissue. Aging Cell 10: 239-254.

Trüeb RM. 2005. Aging of hair. J Cosmet Dermatol 4: 60-72.

Turksen K, Kupper T, Degenstein L, Williams I, Fuchs E. 1992. Interleukin 6: Insights to its function in skin by overexpression in transgenic mice. Proc Natl Acad Sci 89: $5068-5072$.

Tyner SD, Venkatachalam S, Choi J, Jones S, Ghebranious N, Igelmann $\mathrm{H}, \mathrm{Lu} \mathrm{X}$, Soron G, Cooper B, Brayton C, et al. 2002. p53 Mutant mice that display early ageing-associated phenotypes. Nature 415: 45-53.

Uezumi A, Ito T, Morikawa D, Shimizu N, Yoneda T, Segawa M, Yamaguchi M, Ogawa R, Matev MM, Miyagoe-Suzuki Y, et al. 2011. Fibrosis and adipogenesis originate from a common mesenchymal progenitor in skeletal muscle. $J$ Cell Sci 124: 3654-3664.

Uzum AK, Yucel B, Omer B, Issever H, Ozbey NC. 2009. Leptin concentration indexed to fat mass is increased in untreated anorexia nervosa (AN) patients. Clin Endocrinol (Oxf) 71: 33-39.

Varani J, Spearman D, Perone P, Fligiel SE, Datta SC, Wang ZQ, Shao Y, Kang S, Fisher GJ, Voorhees JJ. 2001. Inhibition of type I procollagen synthesis by damaged collagen in photoaged skin and by collagenase-degraded collagen in vitro. Am J Pathol 158: 931-942.

Wang X-P, Schunck M, Kallen K-J, Neumann C, Trautwein C, Rose-John S, Proksch E. 2004. The interleukin-6 cy- 
G. Rivera-Gonzalez et al.

tokine system regulates epidermal permeability barrier homeostasis. J Invest Dermatol 123: 124-131.

Wanke R, Milz S, Rieger N, Ogiolda L, Renner-Müller I, Brem G, Hermanns W, Wolf E. 1999. Overgrowth of skin in growth hormone transgenic mice depends on the presence of male gonads. J Invest Dermatol 113: 967-971.

Weger N, Schlake T. 2005. Igf-I signalling controls the hair growth cycle and the differentiation of hair shafts. J Invest Dermatol 125: 873-882.

Werner S, Breeden M, Hübner G, Greenhalgh DG, Longaker MT. 1994. Induction of keratinocyte growth factor expression is reduced and delayed during wound healing in the genetically diabetic mouse. J Invest Dermatol 103: 469-473.

Werner S, Krieg T, Smola H. 2007. Keratinocyte-fibroblast interactions in wound healing. J Invest Dermatol 127: $998-1008$

Wertheimer E, Trebicz M, Eldar T, Gartsbein M, Nofeh-Moses S, Tennenbaum T. 2000. Differential roles of insulin receptor and insulin-like growth factor-1 receptor in differentiation of murine skin keratinocytes. J Invest Dermatol 115: 24-29.

Wetzler C, Kämpfer H, Stallmeyer B, Pfeilschifter J, Frank S. 2000. Large and sustained induction of chemokines during impaired wound healing in the genetically diabetic mouse: Prolonged persistence of neutrophils and macrophages during the late phase of repair. J Invest Dermatol 115: $245-253$.

Winer S, Winer DA. 2012. The adaptive immune system as a fundamental regulator of adipose tissue inflammation and insulin resistance. Immunol Cell Biol 90: 755-762.

Wojciechowicz K, Markiewicz E, Jahoda CAB. 2008. C/ $\mathrm{EBP} \alpha$ identifies differentiating preadipocytes around hair follicles in foetal and neonatal rat and mouse skin. Exp Dermatol 17: 675-680.

Wojciechowicz K, Gledhill K, Ambler CA, Manning CB, Jahoda CAB. 2013. Development of the mouse dermal adipose layer occurs independently of subcutaneous ad- ipose tissue and is marked by restricted early expression of FABP4. PLoS ONE 8: e59811.

Won $\mathrm{CH}$, Yoo HG, Park KY, Shin SH, Park WS, Park PJ, Chung JH, Kwon OS, Kim KH. 2012. Hair growth-promoting effects of adiponectin in vitro. J Invest Dermatol 132: 2849-2851.

Yeh WC, Cao Z, Classon M, McKnight SL. 1995. Cascade regulation of terminal adipocyte differentiation by three members of the C/EBP family of leucine zipper proteins. Genes Dev 9: 168-181.

Ying H, Araki O, Furuya F, Kato Y, Cheng S-Y. 2007. Impaired adipogenesis caused by a mutated thyroid hormone $\alpha 1$ receptor. Mol Cell Biol 27: 2359-2371.

Yosipovitch G, DeVore A, Dawn A. 2007. Obesity and the skin: Skin physiology and skin manifestations of obesity. J Am Acad Dermatol 56: 901-916, quiz 917-20.

Zhang J-W, Klemm DJ, Vinson C, Lane MD. 2004. Role of CREB in transcriptional regulation of CCAAT/enhancerbinding protein $\beta$ gene during adipogenesis. J Biol Chem 279: 4471-4478.

Zhang YV, Cheong J, Ciapurin N, McDermitt DJ, Tumbar T. 2009. Distinct self-renewal and differentiation phases in the niche of infrequently dividing hair follicle stem cells. 5: $267-278$.

Ziboh VA, Cohen KA, Ellis CN, Miller C, Hamilton TA, Kragballe K, Hydrick CR, Voorhees JJ. 1986. Effects of dietary supplementation of fish oil on neutrophil and epidermal fatty acids. Modulation of clinical course of psoriatic subjects. Arch Dermatol 122: 1277-1282.

Zimmermann R, Strauss JG, Haemmerle G, Schoiswohl G, Birner-Gruenberger R, Riederer M, Lass A, Neuberger G, Eisenhaber F, Hermetter A, et al. 2004. Fat mobilization in adipose tissue is promoted by adipose triglyceride lipase. Science 306: 1383-1386.

Zouboulis CC, Makrantonaki E. 2011. Clinical aspects and molecular diagnostics of skin aging. Clin Dermatol 29: $3-14$. 


\section{$\&_{\mathrm{CSH}}^{\infty} \&$ Cold Spring Harbor

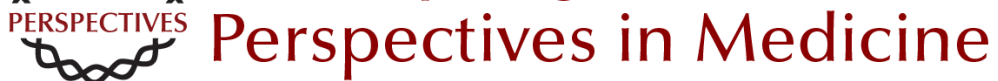

\section{Adipocytes in Skin Health and Disease}

Guillermo Rivera-Gonzalez, Brett Shook and Valerie Horsley

Cold Spring Harb Perspect Med 2014; doi: 10.1101/cshperspect.a015271

Subject Collection The Skin and Its Diseases

Melanoma: Clinical Features and Genomic Insights

Elena B. Hawryluk and Hensin Tsao

Wound Healing and Skin Regeneration

Makoto Takeo, Wendy Lee and Mayumi Ito

The Dermal Papilla: An Instructive Niche for

Epithelial Stem and Progenitor Cells in

Development and Regeneration of the Hair Follicle Bruce A. Morgan

Immunology and Skin in Health and Disease

Jillian M. Richmond and John E. Harris

Desmosomes: Regulators of Cellular Signaling and Adhesion in Epidermal Health and Disease Jodi L. Johnson, Nicole A. Najor and Kathleen J. Green

Markers of Epidermal Stem Cell Subpopulations in Adult Mammalian Skin Kai Kretzschmar and Fiona M. Watt

Psoriasis

Paola Di Meglio, Federica Villanova and Frank O. Nestle

Cell Therapy in Dermatology Gabriela Petrof, Alya Abdul-Wahab and John A. McGrath
Modeling Cutaneous Squamous Carcinoma

Development in the Mouse

Phillips Y. Huang and Allan Balmain

Natural and Sun-Induced Aging of Human Skin Laure Rittié and Gary J. Fisher

Advanced Treatment for Basal Cell Carcinomas Scott X. Atwood, Ramon J. Whitson and Anthony E. Oro

Epidermal Polarity Genes in Health and Disease Frederik Tellkamp, Susanne Vorhagen and Carien M. Niessen

Induced Pluripotent Stem Cells in Dermatology:

Potentials, Advances, and Limitations Ganna Bilousova and Dennis R. Roop

The Genetics of Human Skin Disease Gina M. DeStefano and Angela M. Christiano

p53/p63/p73 in the Epidermis in Health and Disease

Vladimir A. Botchkarev and Elsa R. Flores

Diversification and Specialization of Touch

Receptors in Skin

David M. Owens and Ellen A. Lumpkin

For additional articles in this collection, see http://perspectivesinmedicine.cshlp.org/cgi/collection/ 